UCRL-ID-132899

\title{
Preliminary Definition of Geophysical Regions for the Middle East and North Africa
}

Jerry J. Sweeney

William R. Walter

December 1, 1998

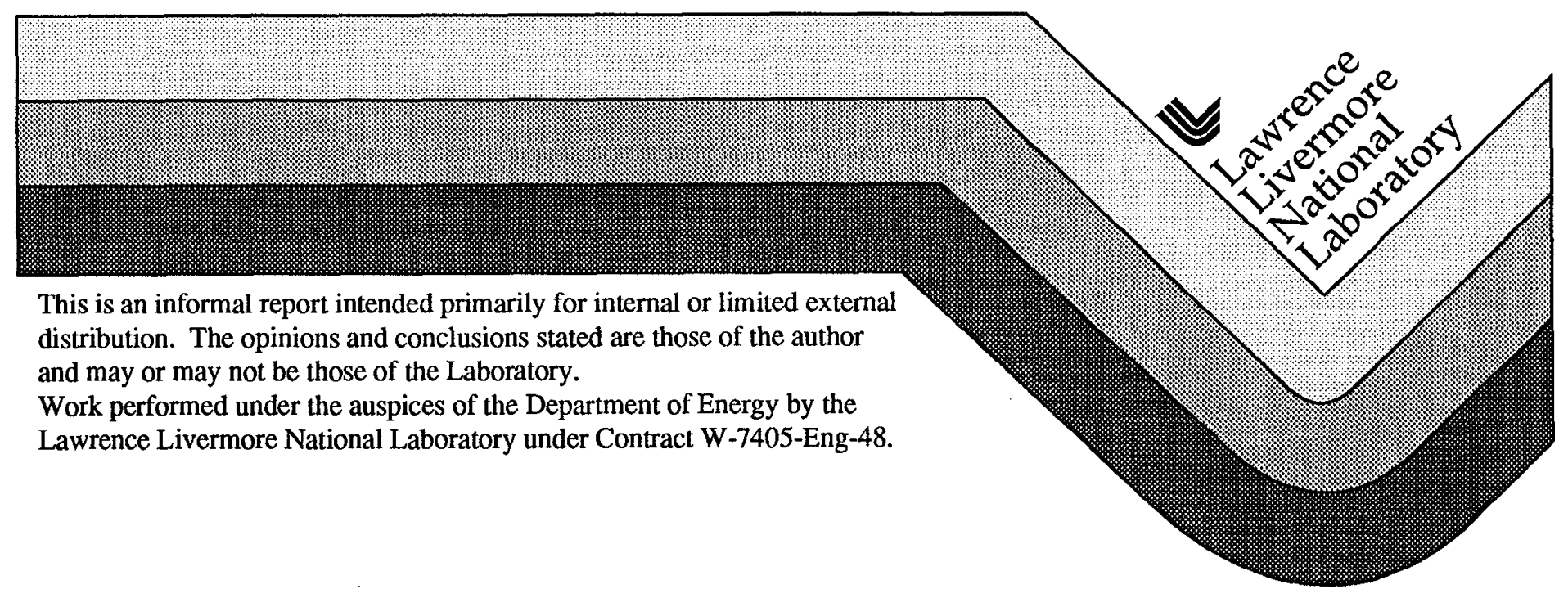




\section{DISCLAIMER}

This document was prepared as an account of work sponsored by an agency of the United States Government. Neither the United States Government nor the University of California nor any of their employees, makes any warranty, express or implied, or assumes any legal liability or responsibility for the accuracy, completeness, or usefulness of any information, apparatus, product, or process disclosed, or represents that its use would not infringe privately owned rights. Reference herein to any specific commercial product, process, or service by trade name, trademark, manufacturer, or otherwise, does not necessarily constitute or imply its endorsement, recommendation, or favoring by the United States Govemment or the University of California. The views and opinions of authors expressed herein do not necessarily state or reflect those of the United States Government or the University of Califomia, and shall not be used for advertising or product endorsement purposes.

This report has been reproduced directly from the best available copy.

Available to DOE and DOE contractors from the Office of Scientific and Technical Information

$$
\text { P.O. Box 62, Oak Ridge, TN } 37831
$$

Prices available from (615) 576-8401, FTS 626-8401

Available to the public from the

National Technical Information Service

U.S. Department of Commerce

5285 Port Royal Rd.,

Springfield, VA 22161 


\title{
Preliminary Definition of Geophysical Regions for the Middle East and North Africa
}

\author{
Jerry J. Sweeney and William R. Walter \\ Geophysics and Global Security Division \\ Earth and Atmospheric Sciences Directorate \\ Lawrence Livermore National Laboratory
}

\begin{abstract}
The ability to calibrate seismic stations to improve the monitoring of the Comprehensive Test Ban Treaty is partially limited by the availability of seismic events with known locations and source properties. To confidently extrapolate from these events to aseismic regions, and to properly account for discontinuities in seismic properties requires accurate geophysical models. This paper lays out a preliminary, first-order, regionalization of the Middle East and North African (MENA) region. The model specifies boundaries and velocity structures based on the geology and tectonics of the region, previously published studies, and empirical data observations by the LLNL group. This model is a starting point and is expected to be improved and refined by comparisons with ongoing tomography efforts and the collection of new data. We anticipate that this model and its successors will prove useful as a background model in the process of forming station calibration maps based on intelligent interpolation techniques such as kriging. We also hope the model, as it improves and demonstrates some predictive power, will provide a reference model for broader CTBT research efforts in detection, location and discrimination as well as other aspects of earth science.
\end{abstract}




\section{Introduction}

Effective seismic monitoring of the Comprehensive Test Ban Treaty (CTBT) involves detection, location, and identification of seismic events of relatively low magnitudes $(\leq 4.0)$ at the regional $(<1500 \mathrm{~km})$ scale.

Accomplishment of this regional monitoring task requires that seismic observation stations, whether single component, multiple component, or arrays, be calibrated. The calibration process is complex: travel time curves must be determined with sufficient accuracy to locate events within $1000 \mathrm{~km}^{2}$; the existence of and characteristics of relevant phases (e.g. Lg, Pn) must be determined in order to use them for discrimination; regional attenuation must be assessed to determine detection and identification limits. All of these factors affecting regional characterization are strongly dependent on regional characteristics of the earth's crust; large differences in the character of seismic propagation in small local regions can strongly affect the performance of a given seismic station or group of stations. Natural seismic sources are the primary data relied on for calibration because artificial sources such as mine explosions are limited spatially, often not large enough, and dedicated calibration explosions are expensive. Seismic sources are of limited spatial extent also, so we need some means to assess the extent of the calibration requirement in areas of sparse seismicity. Our task is somewhat aided by the fact that the areas of lowest seismicity are generally areas with uniform crustal structure and geophysical properties.

Prcvious efforts to develop distinct seismic regions, such as those of Flinn and Engdahl (1965) and Flinn et al. (1974) dealt mainly with seismicity and geography and are inadequate for the purpose of calibration; for example, there are only 4 Flinn-Engdahl regions covering the Middle East and North Africa - see Fig 1 of Flinn et al. (1974). More recent regionalizations (e.g. Jordan, 1981, Mooney et al. 1998) are mainly intended for global use and with resolutions of $5^{\circ}$, their boundaries are still too coarse for our regional 
calibration. The purpose of this report is to define a preliminary set of geophysically distinct regions that can be used for the following purposes:

1.) Provide intelligent estimation of relevant calibration properties, such as attenuation, crustal thickness, crustal velocities, and phase behavior-particularly in aseismic regions where calibration data is sparse.

2.) Provide guidance on spatial parameters affecting calibration, such as the boundaries to be used in determining correlation lengths for regional travel time corrections.

3. Provide a platform for assessing progress in location determination, discrimination, detection-the entire calibration process-and aid in determining the priority of and planning of calibration experiments.

Below we establish a definition of a geophysically distinct region, define an initial set of 28 regions within the geographical area of southern Europe, north Africa, the Middle East and southwestern Asia, establish an initial set of crustal thickness and velocity values for each of the regions, and outline sets of additional data that can be incorporated into this working model. We emphasize that this paper represents the starting point for an iterative process; this initial set of regions will be built upon and modified as additional data are acquired and analyses proceed.

\section{Definition of a geophysically distinct region}

Our definition of a geophysically distinct region is the following: a region of the earth's crust, defined to $1^{\circ}$ resolution, for which geophysical properties can be considered uniform for the purposes of regional seismic calibration. The vague nature of this definition is deliberate; we do not profess to know, a priori, what all the geophysical parameters are that uniquely affect regional calibration, so we do not want to be overly restrictive at the beginning. Experience tells us, however, that factors such as tectonic 
style (e.g. collisional orogen, continental extension, Archaean crust with thin sediments), crustal velocity profiles, and regional phase character will be important. The most difficult part of the definition process is how to determine a level of uniformity. For example, the Arabian plate consists of crystalline basement covered with sedimentary cover varying in thickness from zero to over $10 \mathrm{~km}$. What variation in the thickness of sedimentary cover can be considered to be within a workable definition of "uniform"? At this point we don't know the answer, so we establish a set of working hypotheses. In the present case we have made such decisions in a way that minimizes the number of distinct regions. Reasoning for such decisions in each region are discussed below.

In defining the geophysically distinct regions outlined in this report, we have relied on several sources of information; they are listed below:

1.) A tectonic map of the world, produced by Exxon corporation; Kaplan et al. (1985).

2.) The ETOPO5 digital topography and bathymetry database.

3.) Global seismicity location and depth catalogs currently stored in the Lawrence Livermore National Laboratory (LLNL) seismic database, primarily the National Earthquake Information Center (NEIC) Preliminary Determination of Epicenter (PDE) listings, among others.

4.) The Crust5.1 world crustal thickness and velocity model developed by Mooney et al. (1998).

5.) A search of published literature concerning gcophysical properties of the Middle East and North Africa.

6.) Ongoing studies at LLNL of regional phase propagation characteristics and discriminant effectiveness.

A major difficulty in estimating lithospheric structure in the Middle East and North Africa is the nearly complete lack of large scale refraction profiles and other seismic investigations that have been performed in the 
region, particularly in comparison to North America, Europe and Asia. For this reason we made use of CRI TST5.1 (Mooney et al., 1998) which uses geophysical analogy to estimate structure in regions without data by comparison to regions with similar geology and tectonic history that do have data. In many cases we have modified or substituted a different CRUST5.1 model in the 28 regions, but in all cases we have stuck with the CRUST5.1 eight layer velocity structure format: (1) ice, (2) water, (3) soft sediments, (4) hard sediments, (5) crystalline upper crust, (6) middle crust, (7) lower crust, and (8) uppermost mantle (Pn, Sn velocities).

The regions described below have been selected primarily on the basis of seismicity patterns, tectonic style, crustal thickness, and crustal velocity (including upper mantle). Eventually, other types of data, which are currently being developed by LLNL, Los Alamos National Laboratory (LANL), and Sandia National Laboratory (SNL), Department of Energy (DOE) contractors, and academic institutions will be incorporated into the regional models and used to test and modify the shape and properties of each region designation. Some of these additional data types are:

1.) Characteristics of regional phase propagation, such as path corrections, attenuation $(\mathrm{Q})$, and phase blockage maps.

2.) Tomographic maps of Pn velocity.

3.) Surface wave group and phase velocity tomography maps.

4.) Receiver function estimates of crustal thickness

5.) Regional broadband waveform modeling

6.) Correlation maps and travel time corrections for regional stations.

\section{The Geophysical Regions and Their Characteristics}

The preliminary set of 28 regions is illustrated, superimposed on a map with ETOPO5 topography and bathymetry and NEIC PDE seismicity of events 
of $\mathrm{mb}>4.3$ between 1977 and 1997, in Figure 1. The figure is gridded at $1^{\circ}$ of latitude and longitude. The regions vary in size and encompass a very wide range of tectonic styles, from Archaean shield with thin sedimentary cover in North Africa to deep sedimentary basins with tens of kilometers of sediments over probable oceanic crust in the Caspian Sea. This wide variety reflects the diversity of tectonic plate interactions in the Middle East/North Africa region. Below we discuss some of the characteristics of each region that uniquely define it for our purposes. Table 1 gives a listing each region and some of the characteristics, such as sediment thickness and crustal velocity, which define it. Velocity models for each region are listed in the Appendix.

Region \#1 - Oceanic crust of the Atlantic and Indian Oceans.

Since our primary purpose for this paper is to define properties of continental geophysical regions, definition of this region is mostly pro forma. Region 1 encompasses the continental platform areas and deeper oceanic areas of the Atlantic ocean and Indian oceans proximal to Africa, Europe, and central Asia. It also includes oceanic spreading centers in the Gulf of Aden and Indian ocean. So defined, this region includes quite a variety of crustal types: continental margins, older oceanic crust with thin sedimentary cover, and young oceanic crust with spreading ridge. In order to account for all of these different crustal types it may make sense to subdivide this region further, perhaps on the lines of (Mooney et al., 1998), but for now we have chosen to simplify by defining this region as typical oceanic crust with sediment thickness varying from 0 to $5 \mathrm{~km}$ (Mooney model A0-A5-normal oceanic crust, with variable sediment thickness). Note that here and for all of the rest of the models we adjust the mantle shear velocity to be consistent with a $\mathrm{Vp} / \mathrm{Vs}$ ratio of 1.77 , after Mooney et al. (1998).

Region \#2 - Oceanic crust of the deep Mediterranean. 
This region consists of deep basins underlain with oceanic crust in the western and eastern Mediterranean Sea. Sediment thicknesses are 0-10 km and the oceanic crust below is somewhat thicker than normal oceanic crust. In the western Mediterranean there is halokinesis in the upper part of the sediment column; evaporite (P velocity $3.5 \mathrm{~km} / \mathrm{s}$ ) and halite (P velocity 4.5 $\mathrm{km} / \mathrm{s}$ ) units can be up to $600 \mathrm{~m}$ and $1000 \mathrm{~m}$ thick, respectively. Below these are as much as $4000 \mathrm{~m}$ of sediments with oceanic basement. As is the case with normal oceanic crust, the $\mathrm{Lg}$ phase does not propagate through this type of crust. Mooney uses velocity models B3 and B4 (melt affected oceanic crust and oceanic plateaus, with $3.5-5 \mathrm{~km}$ of sediments). We suggest using a modified model B4 for this region, with a slightly lower Pn velocity than that of B4.

Region \#3 - Deep basins of the Black Sea and southern Caspian Sea.

The effects of the south Caspian Sea area on Lg propagation are well known. Priestley (1997) noted the lack of a "granitic layer" in the crust beneath the south Caspian Sea. This can be interpreted as being an oceanic-floored basin. Sediments are very thick in the south Caspian-up to $15 \mathrm{~km}$ or more. Priestly also modeled shear wave propagation across the basin and determined velocities and attenuation values. The Black Sea basin has been interpreted similarly by Zonenshain and Le Pichon (1986)--they compare 10$15 \mathrm{~km}$ of sediments in the Black Sea with their estimate of $20 \mathrm{~km}$ of sediments in the south Caspian Sea. Zonenshain and Le Pichon also note the lack of a granitic layer in seismic profile data produced by workers of the Former Soviet Union (FSU). They interpret the basement as being oceanic floor, of Tethyan (Jurassic or older-greater than $150-210$ m.y.) with velocities of $6.8-7.0 \mathrm{~km} / \mathrm{s}$; mantle velocities are $8.1-8.2 \mathrm{~km} / \mathrm{s}$. (Priestley interprets an $18 \mathrm{~km}$ thickness of a crystalline basement in the south Caspian Sea.) Both regions are characterized by thick sediment sequences with a lack of granitic layer and rapid transitions to continental crust on the margins. Zonenshain and Le Pichon also mention the presence of a large negative frec- 
air gravity anomaly (-150 to $-250 \mathrm{mGal}$ ) over the south Caspian basin. Sediments are deformed in the south Caspian basin, and mud volcanoes and drilling reveal overpressured sediments to depths of several kilometers, which are not noted in the Black Sea. These overpressured sediments will have unusually low seismic velocities for their depth because abnormal pore pressure inhibits the normal compaction trend with depth. The Mooney model for the south Caspian is D2 - platform with $10 \mathrm{~km}$ of sediments; this is probably not appropriate. The Mooney model for the Black Sea is more reasonable-Y2, intermediate continental/oceanic crust Black Sea. We propose using a modification of model $\mathrm{Y} 2$ for this region to match more closely with the slightly lower $(8.0 \mathrm{~km} / \mathrm{s}$, rather than $8.15-8.20 \mathrm{~km} / \mathrm{s}) \mathrm{Pn}$ velocities observed by Priestley and Mangino (1996). Without resolving the question of $15 \mathrm{~km}$ or $20 \mathrm{~km}$ sediment thickness, we propose using the $18 \mathrm{~km}$ value in model $\mathrm{Y} 2$.

Region \#4- Red Sea Continental Rift Zone

This is a zone of continental rifting between the Arabian plate and the African plate. The Red Sea and Gulf of Aden are the geographic expressions of this zone, although the actual lateral boundaries are more difficult to define. In general, the crustal transition from continental to oceanic spreading ridge (center of the rift-especially in the south-central part of the Red Sea) is relatively abrupt on the western (Egyptian) side and more gradual on the eastern (Saudi Arabia) side. There is quite a lot of data available for the region, including seismic refraction profiles. Hadiouche and Zurn (1992) used 20-250 s period Rayleigh wave inversion of phase and group velocities to estimate the African plate thickness at $43-45 \mathrm{~km}$ in the region; Arabian plate thickness was found to be $45-47 \mathrm{~km}$, with a crustal thickness of $30 \mathrm{~km}$ in the Red Sea region. Marzouk and Makris (1990) interpreted deep seismic sounding (DSS) lines across the Red Sea and found crustal thickness of the Egyptian continental crust to be $28-34 \mathrm{~km}$, thickening to the west, with much thinner crust, about $17 \mathrm{~km}$, in the central part of the Red Sea. They also provide velocity profiles 
for these regions. Bayer et al. (1989) provide velocity profiles for the northcentral Red Sea, Gulf of Aden, and the western Saudi Arabian continental margin. Pn velocities and crustal thickness vary considerably over this profile. Rihm et al. (1991) interpret the same data as Bayer et al.; they emphasize the sharper crustal transition from oceanic to continental on the Egyptian side of the Red Sea. Mooney uses model Y1 - thinned continental crust, Red Sea, for this region. In general this model agrees with the work referenced above, although we have modified the model to have lower Pn velocity $(7.90 \mathrm{~km} / \mathrm{s}$ vs. $8.15 \mathrm{~km} / \mathrm{s})$.

Region \#5 - African platform

This is the region of Paleozoic to Proterozoic basement, with relatively thin sediment cover, making up most of the African continent. The eastern boundary of this region consists of the Red Sea continent to oceanic ridge transition and the East African rift highlands. The western boundary is the abrupt transition to oceanic crust of the Atlantic with the Atlas orogenic belt to the northwest. We have chosen to treat the northern boundary of the African platform, where the continental crust is thinner, more faulted, and with deeper sedimentary basins, as region $\# 8$ because of the probable effect of the sediments on seismic wave propagation. As defined, the African platform region is relatively uniform, except for some crustal thinning at the margins in eastern Egypt and towards the Atlas ranges. There are few regional studies of crustal structure in this region. Sandvol et al. (1998a) give receiver function estimates of crustal thickness at three stations (TAM, DBIC and BNG) which range from $38-43 \mathrm{~km}$. Hazler (1998) has divided the region into several large blocks and examined the Rayleigh wave group velocity curves and inferred structure. Within this region, her most recent results show only small differences in the group velocity curves that may be mainly due to small changes in sediment thickness. Lacking any detailed studies in these regions for velocity and crustal thickness, we have decided to use the Mooney models for this region, which are based on analogies from other shield 
regions in North America and central Asia. Mooney uses at least 9 different crustal models over this region, but mostly they are small modifications of crustal thickness and sediment thickness. We have chosen the Mooney model I7 - late Proterozoic, $1 \mathrm{~km}$ sediments, with a $42 \mathrm{~km}$ thick crust as being most representative of the entire region.

Region \#6 - Arabian platform, thin sediments

This is the western and southeastern part of the Arabian plate where sediment cover is relatively thin to non-existent. The region is bounded on the southwest by the transition to the Red Sea rift, on the southeast by the abrupt continent-ocean transition into the Gulf of Aden/Indian Ocean, and to the northeast by a gradual transition to Arabian plate covered with thicker sediments as the basement dips to the northeast. In the extreme northeast the region boundary is the Dead Sea Fault Zone (DSFZ) along the borders of Israel, Lebanon, Jordan, and Syria. The extreme northern boundary is the south Anatolian Fault zone and the beginning of the continental collision zone of Turkey and the Caucasus. The Arabian plate is moving NNE and colliding with central Asia and the eastern European platform. The Black Sea and southern Caspian Sea mark remnants of the formerly-extensive Jurassic Tethys ocean that have been isolated by the northward movement of Africa and Arabia. In the process of the collision, the region of Turkey, to the west, and the Iranian plateau to the east are being forced out laterally to accommodate the northward motion of Arabia. The Arabian plate dips beneath the Iranian plateau where the Zagros orogenic zone occurs. We have chosen to divide the Arabian plate into two regions. Region \#6 has sediment cover less than $2 \mathrm{~km}$ thick, while region \#7 is the area where sediment cover is greater than $2 \mathrm{~km}$. In region \#6, Precambrian basement rocks are exposed at the surface along the margins of the Red Sea and Gulf of Aden. At the extreme northern end of this region, sediment thickness may be slightly greater than $2 \mathrm{~km}$ in the foredeep areas of the Palmyride fold belt of Syria. 
Also, the crust is slightly thinner near the northeastern boundary in western Jordan and Syria.

Several refraction lines have been obtained in the region and there are several reports concerning determinations of crustal thickness and crustal velocity. El Isa et al. (1986) describe crustal thickness as $37-44 \mathrm{~km}$ in central Jordan with Pn velocities of $8.0-8.15 \mathrm{~km} / \mathrm{s}$ and weak propagation of $\mathrm{Sn}$ in the region. Badri (1991), in an interpretation of a long refraction line in southcentral Saudi Arabia, finds the crust $42 \mathrm{~km}$ thick, thinning to $38 \mathrm{~km}$ in the southeast towards the Red Sea. Mechie et al., (1986), interpreting the same seismic line as Badri [see also Mooney (1985), Healy et al., (1982), and Mooney (1984)] observed a sharp $20 \mathrm{~km}$ transition to shallower Moho as the line goes into the Red Sea shelf along the southwestern margin of the Arabian plate. The refraction line results also indicated that Pn velocity decreases from 8.2 near Riyad to $8.0 \mathrm{~km} / \mathrm{s}$ as the crust thins near the Red Sea. Recently Sandvol et al. (1998b) have looked at receiver functions of stations temporarily deployed in Saudi Arabia in 1995-1997 and obtained results consistent with the refraction line interpretations. Rodgers et al. (1998) modeled seismic waveforms from the Gulf of Aquaba to the Saudi temporary stations and finds a somewhat slower, shallower crust $(36 \mathrm{~km})$ with slower Pn velocities $(7.9 \mathrm{~km} / \mathrm{s})$ than the refraction line results. Slow Pn velocities are also consistent with preliminary Pn (McNamara et al., written comm.) and surface wave (Pasyanos et al., written comm.) tomography results being carried out at LLNL. Aspects of crustal thickness and crustal velocities in the northernmost (Syria) part of this region are discussed by Barazangi et al. (1993). Seber and Mitchell (1992) studied shear wave attenuation $\left(Q_{\beta}\right)$ for 5-30 $s$ amplitude spectra within the Arabian plate.

Mooney uses several different models for the Arabian plate, depending on crustal thickness, which varies from $39-46 \mathrm{~km}$, and sediment thickness which varies from zero to $6 \mathrm{~km}$. The model we propose in this region, a modified $\mathrm{I} 2$ with a reduced Pn velocity, is generally consistent with previous work and a general average for the region with less than $2 \mathrm{~km}$ of sediments. 
Region \#7 - eastern Arabian platform, sediments thicker than $2 \mathrm{~km}$

The discussion above for region \#6 gives the reasoning for separating the Arabian plate into two regions. This eastern half of the Arabian platform is comprised of the part of the plate that has been tilted away from the uplifted Red Sea region and, at its extreme northeastern end, is being pushed beneath the Iranian plateau (region \#15). The southern and western boundary of this region are defined by the $2 \mathrm{~km}$ sediment isopac. The sedimentary cover increases in this region from $2 \mathrm{~km}$ in the west to $10 \mathrm{~km}$ or more in the east under the Persian Gulf and in the foreland basin, which is being filled from the Zagros highlands. Rodgers et al. (1998) using waveform modeling of a Zagros event to Saudi stations, estimate a crustal thickness of $40 \mathrm{~km}$ with an slow average $P$ velocity $(<6.3 \mathrm{~km} / \mathrm{s})$ and a Pn velocity of $8.1 \mathrm{~km} / \mathrm{s}$. The continuously-varying sediment thickness poses a problem here for a "uniform" geophysical region-we have chosen to use a modification of the Mooney D2 (platform, $10 \mathrm{~km}$ sediments), with a slightly lower Pn velocity, for this region.

Region \#8 - North Africa marginal basins

In the discussion for region \#5 we gave the reasoning for making a separate region for the northern margin of Africa. This region encompasses the continental margin transition area of north Africa and the western Mediterranean. The southern boundary of the region is defined approximately by the $2 \mathrm{~km}$ sediment isopac. The northern boundary is the Mediterranean sea oceanic crust of region \#2. The eastern boundary is defined by the DSFZ, with Israel, Lebanon, and Sinai considered part of region \#8. Characteristics of the basins of Libya and western Egypt are outlined by Doser et al. (1995; Suleiman and Doser, (1995). The Levant coast of Israel and Lebanon, and to some extent, Sinai, represent a gradual transition from continental crust along the DSFZ to oceanic crust somewhere to the west (but not as far as the Mediterranean coast)-see Ginzburg (1979) and Biju-Duval et 
al. (1974) for details. The thinned continental crust in the Levant is typically $27-35 \mathrm{~km}$ thick, with Pn velocities typically $8.0-8.1 \mathrm{~km} / \mathrm{s}, P g 5.8-6.4 \mathrm{~km} / \mathrm{s}$ (El-Isa et al., 1986; Khair et al., 1993). In the near surface, velocities are $3.3-3.9 \mathrm{~km} / \mathrm{s}$ in the Tertiary-Mesozoic sediments, which are up to $1.5 \mathrm{~km}$ thick, and 4.7-6.4 $\mathrm{km} / \mathrm{s}$ in the Paleozoic to Precambrian deeper sediments (3.0-3.5 km thick). Sandvol et al. (1998a) give crustal thickness estimates from receiver functions at KEG in Egypt and BGIO in Israel of $33 \mathrm{~km}$ for each. Not much information is available for crustal thickness and velocities in the Libya and western Egypt parts of this region, but they are probably not too different from those of the eastern Mediterranean, with the exception of the Sirt Basin, a deep faultbounded basin in Libya. In the region of the Nile delta we should expect a large cone of thick younger sediments. Mooney uses model S4 and S5 (continental slope/margin transition, $5.5-8 \mathrm{~km}$ sediments) in this area. We have chosen a modified (slightly lower Pn) model T5 (margin/shield transition, $5 \mathrm{~km}$ sediments) for this region as being more appropriate.

Region \#9-Atlas - Betic orogenic zone

This region consists of the northwestern corner of the African continent, which includes most of Morocco, northern Algeria, and most of Tunisia, and the southern half of the Iberian peninsula of Spain including the western end of the Alboran Sea near Gibraltar. The region is a continental collisional orogenic zone, but crustal thicknesses are somewhat less than for the orogenic zones in Turkey and Iran. The European Geotraverse (EGT) group (Research, 1992) completed a deep seismic refraction profile from the Sardinian channel of the Mediterranean Sea, north of Tunisia, south onto the African continent, in 1985. The EGT experiment found the Moho to be 30-35 $\mathrm{km}$ deep in south-central Morocco and much thinner-21 km-off shore in the Sardinian channel, with approximately $13 \mathrm{~km}$ of sedimentary cover. Sandvol et al. (1998a) using receiver functions estimate crustal thickness at MDT in Morocco at $36 \mathrm{~km}$ and at PAB and TOL in Spain at $34 \mathrm{~km}$. Makris et al. (1985) reported on a deep seismic sounding experiment in Morocco. For 
the SW-NE line in central Morocco, they found Pn to be $7.8 \mathrm{~km} / \mathrm{s}$ with a crustal thickness of $30 \mathrm{~km}$. Further inland, beneath the Anti Atlas Range, the crust was found to be $34 \mathrm{~km}$ thick with Pn $8.0 \mathrm{~km} / \mathrm{s}$. Marillier and Mueller (1982) found the Pn in Morocco and Spain, near Gibraltar, to be about 8.1 $\mathrm{km} / \mathrm{s}$.

Mooney uses three different crustal models in the region, N2, N4, and T6. These are extended crust and margin/shield models, respectively, with sediment thickness from $1-3 \mathrm{~km}$. We choose the T6 model, with $1 \mathrm{~km}$ sediment cover, as most representative and compatible with the refraction seismic data.

Region \#10-Kopet Dagh-Alboran orogenic belt

This region marks the northern edge of the Iranian plateau, which is pushed northward against the southern Caspian basin and central Asia. The crust in this region has been thickened by collision and heated by volcanism, at least south of the Caspian Sea. As mentioned in the discussion of region $\# 3$, there is a strong contrast in crustal thickness and velocity between this orogenic zone and the south Caspian basin. Velocity profiles have been determined by Priestley and Mangino (1996) and Priestley (1997) from receiver functions for seismic stations around the Caspian Sea. They found crustal thickness to be greater than $45 \mathrm{~km}$ in the region of the ABKT (Alibek) seismic station east of the Caspian, in Turkmenistan near the Iranian border. Hearn and Ni (1994) and Rodgers et al. (1997) have noted that Sn propagation is very weak in this region. The Mooney model for this area is D2 and D4-platform with 5-10 km sediments. Model P1 (orogen, $46 \mathrm{~km}$, Tethyan orogen, $2 \mathrm{~km}$ sediments) is probably a better choice here.

Region \#11-Caucasus orogenic belt

This region between the Black Sea and Caspian Sea has many similarities with region \#10. It consists of thickened crust due to continental collision. We have separated this region from $\# 10$ because of a difference in 
phase behavior-Lg propagates poorly in this region, while it propagates well in region \#10. Velocities of the shallow crust here have been determined from analyses of aftershocks of the Spitak [Dorbath et al. (1992)] and Racha, Georgia [Fuenzalida et al. (1997b)] earthquakes. Sandvol et al. (1998a) give a crustal thickness estimate of $43 \pm 5 \mathrm{~km}$ at station $\mathrm{KIV}$ at the northern boundary of this region from receiver functions. The Mooney model here, Q0 (orogen, $46 \mathrm{~km}$, no ice) is probably a good choice.

Region \#12-Zagros fold and thrust zone

The Zagros mountain range is a zone of continental collision between the Arabian plate and the Iranian plateau. Berberian (1995) and Berberian and King (1981) describe the Zagros as a fold-thrust belt as having a detachment at a depth of about $10 \mathrm{~km}$. A very thick sedimentary section is involved, with a possible doubling of the crust. The eastern boundary of this region is marked by the Main Zagros Thrust (MZT) where the oldest rocks are most deformed and uplifted. Extensive halokinesis occurs within the fold belt, involving salt diapirs and tongues along thrust fault planes. The infracambrian salt formation (which is up to $1 \mathrm{~km}$ thick) has been called upon to be the location of major decollements (large overthrust planes). Berberian (1995) estimates a Moho at $45 \mathrm{~km}$ beneath the Persian Gulf and $60 \mathrm{~km}$ beneath the MZT. Berberian speculates on a "frictional seismogeneic zone" at 8-12 km depth under Zagros, with the base of the Paleozoic sediments at about $8 \mathrm{~km}$. The database of the Institute for the Study of the Continents (INSTOC) at Cornell University shows a sediment thickness (depth to basement) reaching $>12 \mathrm{~km}$. Snyder and Barazangi (1986) estimate $6-12 \mathrm{~km}$ of sediment cover with a Moho dipping about $1^{\circ}$ to the northeast under the foreland (Persian Gulf side) and $5^{\circ}$ near the MZT. The zone of crustal thickening is probably widest in the region northwest of Hormuz and gradually narrows to the northwest, where it merges with the Anatolian faults in Turkey and Syria. The thick crust, thick deformed sediment pile, and halokinesis in the shallow crust are what distinguish this block from the Arabian shield and Iranian plateau. 
The Mooney model for this region is D4-platform with $5 \mathrm{~km}$ of sediments. This is not thick enough and the sediment pile is too thin. A better model might be R0-orogen, Tibet transition, but with $50 \mathrm{~km}$ thick crust modified for a thicker sediment pile. The model given in Table 1 and the Appendix accounts for the crust and sediment thicknesses.

Region \#13-Eastern Anatolia, southern Caucasus

This region is part of the Turkish-Iranian plateau, a continental collisional zone that is topographically high, has low Pn velocities and inefficient Sn propagation [e.g. Rogers et al. (1997)]. We have split it apart from other parts of the plateau (regions \#14 and \#15) as well as nearby orogen belts [regions \#11 and \#12] because it appears to have some unique regional seismic phase characteristics, although more work is needed to really define these regions fully. The area is characterized by Quaternary volcanism and strong regional phase attenuation. This is a region of continental collision with thickened crust, but it also marks the eastern end and convergence zone of the North and South Anatolian faults, two major strike-slip faults that accommodate the westward motion of Turkey as the Arabian plate moves northward. The Erzincan earthquake of 1992 was extensively studied Fuenzalida et al. (1997a); the aftershock study provides estimates of upper crustal velocity structure. Sandvol et al. (1998a) give a surprisingly thick crustal thickness estimate of $64 \mathrm{~km}$ at GNI from receiver functions. A closer look at the models and their discussion reveals another possible interpretation of a Moho at $43 \mathrm{~km}$ with a second discontinuity at $64 \mathrm{~km}$. We favor this later interpretation. Mooncy uses model P1-orogen, $46 \mathrm{~km}$ crust, Tethyan orogen, $2 \mathrm{~km}$ sediments-here. We have no reason to change this.

Region \#14-Turkish plateau

In this region, central Turkey is being uplifted and squeezed to the west as a result of Arabia-Asia collision in eastern Turkey and the Caucasus. The western boundary of this region is where the structural style merges into the 
region of extensional tectonics of western Turkey and the Aegean. The southern and northern boundaries are marked roughly by the south and north Anatolian faults (strike-slip). The island of Cyprus is included in this region, following the results of a seismic profile described by Makris et al. (1983). Sandvol et al. (1998a) give a crustal thickness estimate at ANTO of 37 $\mathrm{km}$ based on receiver functions. What distinguishes this region from \#13 is some evidence for more efficient propagation of Lg. Note that the region of inefficient $\mathrm{Sn}$ propagation is only in the northern part of this region, $\mathrm{Sn}$ is seen in southern Turkey and Cyprus and Lg is not seen for paths offshore south of Turkey [Rodgers et al. (1997)], so in the future there may need to be further subdivision of Turkey based on the regional wave propagation. The Mooney model here (P1) is the same as for region \#13, and we have chosen to stay with that for now.

Region \#15-Iranian plateau

The Iranian plateau is an elevated $(>2000 \mathrm{~m})$ and relatively less seismically active part of Iran caught between the Zagros collision zone to the southwest and Alborz-Caspian-Kopet Dagh (region \#10) collision zone to the northeast. The indentation of Arabia into Asia forces the Iranian plateau to the east, but this "escape" is blocked by the northward movement of the Indian plate. Thus the eastern part of the Iranian plateau is in collision with Afghanistan and Pakistan. The Lut block in the eastern Iranian plateau is considered part of the plateau for our definition, but is somewhat distinct geologically and tectonically. The MZT, which also delimits the northeastern extent of 7agros seismicity, is considered the southeastern boundary of this region. The only refraction data known for this region is that reported by Giese et al. (1984) that used mine explosions for sources and ran along the southwestern side of the Lut block, just northeast of Hormuz. In this study they interpreted the crust to be $60 \mathrm{~km}$ thick under the Zagros ranges, and this thickened crust extended laterally up to $60 \mathrm{~km}$ northeast of the MZT, with a 
sharp transition to 35 thick crust under the Lut block. This implies a very abrupt crustal transition between the Iranian plateau and the Zagros fold belt.

In an earthquake aftershock study of the Rudbar earthquake near Tabriz in northwestern Iran, Tsukuda et al. (1991) noted a $40 \mathrm{~km}$ thick crust, with Pn velocities of $8.0-8.1 \mathrm{~km} / \mathrm{s}$. Berberian (1982) found the crust to be 44 $\mathrm{km}$ thick in northeastern Iran, at the location of the 1978 Tabas earthquake, with a Pn velocity of $8.0 \mathrm{~km} / \mathrm{s}$. These Pn velocities are consistent with LLNL studies of propagation to the ILPA array near Tehran and with work by others, such as Rodgers et al. (1997). Rong-Song Jih (1993) studied Lg attenuation in the Iranian plateau. Jih found $\operatorname{Lg} \mathrm{Q}$ at $1 \mathrm{~Hz}$, to be 181-183 within the Lut block, 201-210 in the northern Kopet Dagh region, and 250 in the Alborze and central Iran areas. As in region \#14, the region of inefficient Sn propagation is limited to the northern part of the plateau [Rodgers $e t$ al. 1997) and so this region may require further subdivision. The Mooney model for this region is $\mathrm{P} 1$-orogen, $46 \mathrm{~km}$ crust, $2 \mathrm{~km}$ sediments, which is adequate for our purposes.

Region \#16-Makran margin of southern Iran and Pakistan

This is also a region of plate collision, but we separate it from region $\# 12$, Zagros, and region \#15, Iranian plateau, because this is a region of oceanic collision (in this case subduction) beneath southern Iran and Pakistan. Byrne et al. (1992) show that subduction of oceanic crust in this region is probably low angle, and the trench is choked with a very large sediment influx from the outflow of the Indus river. A line of active volcanoes occurs about $500 \mathrm{~km}$ north of the southerly limit of deformed sediments in the trench, consistent with a subduction zone geometry. Byrne et al. found contrasting styles of deformation in eastern and western Makran, the dividing line being roughly the Iran-Pakistan border. They found sediment velocities to be lower and upper mantle velocities to be slightly lower $(7.9 \mathrm{~km} / \mathrm{s}$ compared to $8.0 \mathrm{~km} / \mathrm{s})$ in eastern Makran than western Makran. The oceanic subduction in Makran has been more or less continuous 
since early Cretaceous time (at least $100 \mathrm{~m} . \mathrm{y}$. ). Seismicity in the region is sparse, and Laane and Chen (1989) make comparisons between Makran and the Cascadian margin of Washington State and Oregon. The best velocity/crustal model for this region is probably a modification of Mooney L1 (continental arc, Cascades) with an adjustment for thick sediments.

Note: Regions \#17-\#28 are outside of the boundaries of what we have generally referred to as the Middle East/North Africa region, but we are including them here because many propagation paths used to characterize the Middle East/North Africa region travel through these regions. Because we have not gathered as much data on the following regions, the descriptions to follow will be somewhat more abbreviated than those above.

Region \#17-Aegean and western Anatolia back-arc extensional area

This is the region of western Turkey and southern Greece in which crustal extension is taking place northward of the Aegean arc.

Panagiotopoulos and Papazachos (1985) found Pn in Greece to be 7.8-8.0 km/s. Nishigami et al. (1990) determined very local coda $Q$ values from a microseismicity array in western Turkey. Mindevalli and Michell (1989) state that "...crustal velocities are slightly lower and upper mantle velocities are slightly faster in western Turkey than in eastern Turkey...". The value of 7.73 $\mathrm{km} / \mathrm{s}$ for Pn beneath Turkey cited by Chen, Chen, and Molnar (1980) seems somewhat low, and Ezen (1991), in a study of Rayleigh wave group velocities to WWSSN station IST, found Pn to be $7.87 \mathrm{~km} / \mathrm{s}$ with a crustal thickness of $31 \mathrm{~km}$. Ezen's study called for a low velocity zone at $15 \mathrm{~km}$ depth in western Turkey. The Mooney models for this region are T7 (margin-shield transition, with $3.5 \mathrm{~km}$ of sediments) for western Turkey and S3 (continental slopemargin transition, $3.5 \mathrm{~km}$ sediments) for western Greece. The T7 model with $34 \mathrm{~km}$ crustal thickness is probably best, although we propose using a lower Pn velocity here $-7.9 \mathrm{~km} / \mathrm{s}$ instead of $8.2 \mathrm{~km} / \mathrm{s}$. 
Region \#18-Afar triangle

This is the focal point of the Red Sea-Gulf of Aden-East African rift triple junction of continental rifting. The crust is oceanic and very thin in this region with high heat flow. Bayer et al. (1989) suggest that the mantle is very shallow in the Gulf of Aden, with crustal thickness of $6.5 \mathrm{~km}$ and Pn velocity of $7.5 \mathrm{~km} / \mathrm{s}$. Sandvol et al. (1998a) get a similar thickness of $8.5 \mathrm{~km}$ from receiver functions at station ATD. Knox et al. (1998) indicate low Pn velocities and a very low uppermost mantle $S$ velocity beneath Afar from two station surface wave phase velocity measures. (They also note this anomaly extends under the southern Arabian shield). This suggests that a model such as Mooney A0, normal oceanic, $0.15 \mathrm{~km}$ sediments, and $6.65 \mathrm{~km}$ crustal thickness, is most applicable, but with a lower $(7.80 \mathrm{~km} / \mathrm{s}$ vs. $8.15 \mathrm{~km} / \mathrm{s}) \mathrm{Pn}$ velocity.

Region \#19-East African Rift Zone

This is an uplifted region of crustal extension with extensive basalt cover that has not yet progressed to the point of sea floor spreading, as in the case of the Red Sea and Gulf of Aden. Mooney uses I7 (late Proterozoic, thicker sediments) with $42 \mathrm{~km}$ thick crust and relatively high Pn for this region. We propose a modification, using model I2 with thinner Proterozoic crust, thinner sediments, and lower Pn velocity.

Region \#20-Caspian depression

The Exxon tectonic map identifies this region as a very deep sedimentary basin, with up to $20 \mathrm{~km}$ of sediments, located within the southcentral Asian platform. The area has extensive salt tectonics (diapirs). Mooney uses model $Y 7$ for this region-Caspian depression, $12 \mathrm{~km}$ sediments, with crustal thickness of $36 \mathrm{~km}$. We have modified this model by adding an additional sediment layer, which makes the crust a bit thicker. 
Region \#21-Kazakhstan-Russian platform

Mooney uses models D6 and D9 here-platform with 1-2 km of sediments and a crustal thickness of $41 \mathrm{~km}$. We choose to use model D9.

Region \#22-Caucasus forelands

These are deep sedimentary basins formed in the foreland of the Caucasus orogenic zone. Mooney uses models D6 and DB here. The main difference is sediment thickness. Sediments are thicker on the eastern side of the region in the Caucasus foreland than they are to the north of the Black Sea. We propose using velocity model D6 here, which has thicker sediments.

Region \#23-Russian platform

This region is similar to \#21. The straight western boundary of this region is marked by the Teisseyre-Tornquist Zone (TTZ), a 20-50 km wide zone making up the boundary between the Precambrian East European Platform (with Paleozoic cover) and the Phanerozoic crust of central and western Europe. This boundary follows the trend identified by Schweitzer (1995). According to Schweitzer, at the northern end of the TTZ in Poland depths to Moho are about $42-47 \mathrm{~km}$ on the eastern side of the TTZ, $30-36 \mathrm{~km}$ on the western side, and 50-55 km within the TTZ. A similar trend is seen further south in Romania; there, as reported by Fan et al. (1998), the Moho is at $40-47 \mathrm{~km}$ on the west side of the TTZ and $30-35 \mathrm{~km}$ deep on the western side. The Mooney model D6, platform with $2 \mathrm{~km}$ sediments and $41 \mathrm{~km}$ thick crust is probably a good start for this Precambrian platform area.

Region \#24-Indus basin - Indian Shield

This is the Indian plate, east of the Makran subduction zone where the Indus river delta occurs. The region is underlain by the precambrian Indian shield, but the sediment cover varies greatly. It gets very thick, up to $10 \mathrm{~km}$ at the margins along the mountains thinning to zero in central India. The area 
discussed here is primarily the western part of the shield. Mooney uses models D9 and DB1 $41 \mathrm{~km}$ thick platform with 1 and $3 \mathrm{~km}$ sediments, for this region. We used the thicker sediment model DB. For time being we treat it as one region but for future work this area may need to be subdivided based on variation in sediment thickness, the continental shelf, and the occurrence of the large Deccan traps basalt flow.

Region \#25- Afghanistan-Hindu Kush orogenic zone

This region is part of the region of intense orogeny due to the collision of India with Asia. Deep seismicity occurs in the center of this region. For the time being we use boundaries mainly based on topography and treat it as one region. Mooney uses model D9, platform, $1 \mathrm{~km}$ sediments with $41 \mathrm{~km}$ thick crust for this region.

Region \#26-Pannonian basin

This region consists of the Alps-Appenine-Dinaride orogen back-arc Pannonian and adjacent, smaller, Transylvanian basins. It is a region of relatively thin crust (depth to Moho about $32 \mathrm{~km}$ ) consisting of Paleozoic basement with Tertiary-Quaternary basin fill sediments. As a start, we propose using Mooney model N4-extended crust, $3 \mathrm{~km}$ sediments, $35 \mathrm{~km}$ thick-for this region.

Region \#27-Alps-Appenines-Dinarides orogenic zone

This is the region of the Alps, northern Italy, the "spine" of Italy, and the Dinaride mountains on the east side of the Adriatic Sea. It is the zone of Tertiary-Quaternary Alpine convergence from the collision of the African plate with southern Europe. Estimates of depth to Moho and Pn velocity of the area are given by Mele et al. (1998). The area is complex, with rapid changes of crustal thickness and Pn velocity over relatively small distances. Generally, depth to Moho is about $40 \mathrm{~km}$, with greatest thickness beneath the Italian Alps. Moho depths are least beneath the Adriatic Sea (25-35 km) but 
rapidly thicken to $40 \mathrm{~km}$ beneath the Apennines to the west and Dinarides to the east. Pn velocities are generally slower on the land $(7.9-8 \mathrm{~km} / \mathrm{s})$ and are normal to fast in the Adriatic Sea and Po plain. Large scale models show more uniformly slow Pn velocities (McNamara, pers. comm.) Mele et al. and other studies note regions of Sn inefficiency extend from the Tyrrhenian Sea into central Italy, consistent with low upper mantle velocities there. The Mooney model P2-orogen, Alps and Foreland, $2 \mathrm{~km}$ sediments, $38 \mathrm{~km}$ Moho, $8 \mathrm{~km} / \mathrm{s}$ Pn velocity, seems a reasonable starting point here.

Region \#28-Paris basin-Massif Central

This is the region of central and southern France which consists of Paleozoic basement which subsided as a foreland basin during the rise of the Alpine orogeny. A map produced by Yegorova et al. (1997) shows depths to Moho here ranging from $28-32 \mathrm{~km}$. The Mooney model for this arca is N3extended crust, $1.5 \mathrm{~km}$ sediments, $31 \mathrm{~km}$ thick crust.

\section{More Work is Needed}

This initial attempt to define a set of geophysically distinct regions is based on first order geophysical data (primarily seismic velocity and crustal thickness), with each region having a set of defined parameters in the form of an average seismic velocity model. As was stated in the Introduction, this initial model represents a starting point; much more work is needed to refine both the crustal properties and boundaries of the regions for the Middle East and North African area. Based on characteristics of empirical data that we are collecting, ongoing seismic tomography studies, and additional data from the literature and contractor results, LLNL should test and refine the definitions of these regions. The refinement will include the values of average properties within the region and the definition of boundaries-including the consolidation of regions or addition of new regions as deemed appropriate. 
Where sufficient data exists, location and discrimination calibration can be done completely empirically, via intelligent interpolation techniques such as kriging (e.g. Schultz et al., 1998). Concurrently it should be possible to refine regional models to fit the data very well in these areas, though resolving conflicts between different datasets will still require much work. Where data is sparse, or significant geophysical boundaries exist, we hope the model will help guiding the extrapolation of calibration parameters to aseismic areas. For example it may provide the background model parameters and boundaries when kriging data. Overall we hope it may prove useful in assessing network performance and capability analysis, to help guide us to areas needing further calibration work.

Finally, we hope the model provokes discussion and can serve as a continually updating reference model to help coordinate between the many various MENA activities being carried out at LLNL and among contractors and in academia. As a starting point, Yu-Shen Zhang under an IUT contract and Bill Walter have made a $1^{\circ}$ block model based on this report, which will be stored in part of the LLNI. database and which we encourage others to test and make suggestions for improvements. We suggest the proper evaluation of the model be based on its ability to predict actual data [e.g. travel times, surface wave dispersion curves, waveform modeling, existence of regional phases, etc], and that the updates to model should improve fits to these datasets.

\section{Acknowledgments}

We thank Jay Zucca for prodding us to do this study. We thank YuShen Zhang for making the initial $1^{\circ}$ block model from our map. This work was performed under the auspices of the U.S. department of energy by the Lawrence Livermore National Laboratory, under contract W-7405-ENG-48. 


\section{References}

Badri, M., 1991, Crustal structure of central Saudi Arabia determined from seismic refraction profiling: Tectonophysics, v. 185, p. 357-374.

Barazangi, M., D. Seber, T. Chaimov, J. Best, and R. Litak, 1993, Tectonic evolution of the northern Arabian plate in western Syria, in E. Boschi et al., ed., Recent Evolution and Seismicity of the Mediterranean Region, Kluwer Academic Publishers, p. 117-140.

Bayer, H.-J., Z. El-Isa, H. Hotzl, J. Mechie, C. Prodehl, and G. Saffarini, 1989, Large tectonic and lithospheric structures of the Red Sea region: Journal of African Earth Sciences, v. 8, p. 565-587.

Berberian, M., 1982, Aftershock tectonics of the 1978 Tabas-E-Golshan (Iran) earthquake sequence: a documented active thin- and thick-skinned tectonic case: Geophysical Journal of the Royal Astronomical Society, v. 68, p. 499-530.

Berberian, M., 1995, Master "blind" thrust faults hidden under the Zagros folds: active basement tectonics and surface morphotectonics: Tectonophysics, v. 241, p. 193-224.

Berberian, M., and G. C. P. King, 1981, Towards a paleogeography and tectonic evolution of Iran: Can. J. Earth Sci., v. 18, p. 210-265.

Biju-Duval, B., J. Letouzey, L. Montadert, P. Courrier, J. F. Mugniot, and J. Sancho, 1974, Geology of the Mediterranean Sea Basins, in C. A. Burk, and C. L. Drake, eds., Geology of Continental Margins, New York, Springer-Verlag, p. 695-721. 
Byrne, D., L. R. Sykes, and D. M. Davis, 1992, Great thrust earthquakes and aseismic slip along the plate boundary of the Makran subduction zone: Journal of Geophysical Research, v. 97, p. 449-478.

Chen, C. Y., W. P. Chen, and P. Molnar, 1980, The uppermost mantle P wave velocities beneath Turkey and Iran: Geophysical Research Letters, v. 7, p. 7780.

Dorbath, L., C. Dorbath, L. Rivera, A. Fuenzalida, A. Cisternas, R. Tatevossian, J. Aptekman, and S. Arefiev, 1992, Geometry, segmentation and stress regime of the Spitak (Armenia) earthquake from the analysis of the aftershock sequence: Geophysical Journal International, v. 108, p. 309-328.

Doser, D. I., G. R. Keller, K. C. Miller, and S. Harder, 1995, Development of a lithospheric model and geophysical data base for North Africa, El Paso, Texas, Department of Geological Sciences, University of Texas El Paso.

El-Isa, Z. H., J. Mechie, C. Prodehl, and J. Makris, 1986, Crustal structure of Jordan and adjacent areas: Results from deep seismic soundings: 3rd Arab Seismological Seminar, p. 59-70.

Ezen, U., 1991, Surface wave dispersion and upper crustal structure along N-S direction in western Turkey from Burdur earthquake of 12 May 1971: Bulletin of the International Institute of Seismology and Earthquake Engineering, v. 25, p. 39-59.

Fan, G., T. C. Wallace, and D. Zhao, 1998, Tomographic imaging of deep velocity structure beneath the Eastern and Southern Carpathians, Romania: Implications for continental collision: Journal of Geophysical Research, v. 103, p. 2705-2723. 
Flinn, E. A., and E. R. Engdahl, 1965, A Proposed Basis for Geographical and Seismic Regionalization: Reviews of Geophysics, v. 3, p. 123-149.

Flinn, E. A., E. R. Engdahl, and A. R. Hill, 1974, Seismic and Geographical Regionalization: Bulletin Of the Seismological Society Of America, v. 64, p. 771-992.

Fuenzalida, H., L. Dorbath, A. Cisternas, H. Eyidogan, A. Barka, L. Rivera, H. Haessler, H. Philip, and N. Lyberis, 1997a, Mechanism of the 1992 Erzincan earthquake and its aftershocks, tectonics of the Erzincan Basin and decoupling on the North Anatolian Fault: Geophysical Journal International, v. 129, p. 128.

Fuenzalida, H., L. Rivera, H. I Iaessler, D. Legrand, H. Philip, L. Dorbath, D. McCormack, S. Arefiev, C. Langer, and A. Cisternas, 1997b, Seismic source study of the Racha-Dzhava (Georgia) earthquake from aftershocks and broadband teleseismic body-wave records: an example of active nappe tectonics: Geophysical Journal International, v. 130, p. 29-46.

Giese, P., J. Markris, B. Akasheh, and e. al., 1984, The crustal structure of southern Iran derived from seismic explosion data: Neues Jahrbuch fur Geologie und Palaontologie Abhandlungen, v. 168, p. 230-243.

Ginzburg, A., J. Makris, K. Fuchs, C. Prodehl, W. Kaminski, and U. Amitai, 1979, A seismic study of the crust and upper mantle of the Jordan-Dead Sea rift and their transition toward the Mediterranean Sea: Journal of Geophysical Research, v. 84, p. 1569-1582. 
Hadiouche, O., and W. Zurn, 1992, On the structure of the crust and upper mantle beneath the Afro-Arabian region from surface wave dispersion: Tectonophysics, v. 209, p. 179-196.

Hazler, S. E., 1998, One-dimensionsal velocity structure of northern Africa as determined by Rayleigh wave group velocity dispersion, Masters Thesis, University of Colorado, Boulder.

Healy, J. H., W. D. Mooney, H. R. Blank, M. E. Gettings, W. M. Kohler, R. J. Lamson, and t. L.E. Leone, 1982, Saudi Arabian seismic deep-refraction profile: Final project report, U. S. Geological Survey.

Hearn, T. M., and J. F. Ni, 1994, Pn velocities beneath continental collision zones: the Turkish-Iranian Plateau: Geophys. Journal International, v. 117, p. 273-283.

Jih, R. S., and C. S. Lynnes, 1993, Regional Lg Q variation in Iranian plateau and its implication for $\mathrm{mb}(\mathrm{Lg})$ determination, Phillips Lab report PL-TR-932003 (TGAL-93-01), p. 13-37.

Jordan, T. H., 1981, Global tectonic regionalization for seismological data analysis, Bulletin of the Seismological Society of America, 71, 1131-1141.

Kaplan, A., C. U. Lusser, and I. O. Norton, 1985, Tectonic Map of the World, Panel 10 (1:10,000,000 Mercator): Exxon Research Company.

Khair, K., M. Khawlie, F. Haddad, M. Barazangi, D. Seber, and T. Chaimov, 1993, Bouguer gravity and crustal structure of the Dead Sea transform fault and adjacent mountain belts in Lebanon: Geology, v. 21, p. 739-742. 
Knox, R. P., A. A. Nyblade and C. A. Langston, 1998, Upper mantle S velocities beneath Afar and western saudi Arabia from Rayleigh wave dispersion, Geophysical Research Letters, 25, 4233-4236.

Laane, J. L., and W.-P. Chen, 1989, The Makran earthquake of 1983 April 18: A possible analogue to the Puget Sound earthquake of 1965?: Geophysical Journal International, v. 98, p. 1-9.

Makris, J., Z. B. Abraham, A. Behle, A. Ginzburg, P. Giese, L. Steinmetz, R. B. Whitmarsh, and S. Eleftheriou, 1983, Seismic refraction profiles between Cyprus and Israel and their interpretation: Geophysical Journal of the Royal Astronomical Society, v. 75, p. 575-591.

Makris, J., A. Demnati, and J. Klubmann, 1985, Deep seismic soundings in Morocco and a crust and upper mantle model deduced from seismic and gravity data: Annales Geophysicae, v. 3, p. 369-380.

Marillier, F., and S. Mueller, 1982, Structure of the upper mantle in the Northeastern Atlantic close to the Azores-Gibraltar ridge from surface-wave and body-wave observations: Tectonophysics, v. 90, p. 195-213.

Marzouk, I., and J. Makris, 1990, Deep seismic profiles in Egypt: Bulletin of the International Institute of Seismology and Earthquake Engineering, Tsukuba, v. 24 , p. $1-40$.

Mechie, J., C. Prodehl, and G. Koptschalitsch, 1986, Ray path interpretation of the crustal structure beneath Saudi Arabia: Tectonophysics, v. 131, p. 333-352.

Mele, G., A. Rovelli, D. Seber, T. M. Hearn, and M. Barazangi, 1998, Compressional velocity structure and anisotropy in the uppermost mantle 
beneath Italy and surrounding regions: Journal of Geophysical Research, v. 103, p. 12529-12543.

Mindevalli, O. Y., and B. J. Mitchell, 1989, Crustal structure and possible anisotropy in Turkey from seismic wave dispersion: Geophysical J. International, v. 98, p. 93-106.

Mooney, W. D., and E. C. Prodehl, 1984, Proceedings of the 1980 workshop of the International Association of Seismology and Physics of the Earth's Interior on the seismic modeling of laterally varying structures:

Contributions based on data from the 1978 Saudi Arabian refraction profile, U.S. Geological Survey report number 937, 158 pages.

Mooney, W. D., M. E. Gettings, H. R. Blank, and J. H. Healy, 1985, SaudiArabian Seismic-Refraction Profile : a Traveltime Interpretation Of Crustal and Upper Mantle Structure: Tectonophysics, v. 111, p. 173-246.

Mooney, W. D., G. Laske, and T. G. Masters, 1998, CRUST 5.1: A global crustal model at $5^{\circ} \times 5^{\circ}$ : Journal of Geophysical Research, v. 103, p. 727-747.

Nishigami, K., Y. lio, C. Gurbuz, A. Pinar, N. Aybey, S. B. Ucer, Y. Honkura, and A. M. Isikara, 1990, Microseismic activity and spatial distribution of coda$Q$ in the westernmost part of the North Anatolian Fault Zone, Turkey: Bulletin of the Disaster Prevention Institute, Kyoto Univ., v. 40, p. 41-56.

Panagiotopoulos, D. G., and B. C. Papazachos, 1985, Travel times of Pn-waves in the Aegean and surrounding area: Geophysical Journal International, v. 80, p. $165-176$.

Priestley, K., 1997, Anomalous wave propagation across the south Caspian basin: 19th Annual Seismic Research Symposium on Monitoring a 
Comprehensive Test Ban Treaty, Defense Special Weapons Agency, p. 534542.

Priestley, K., and S. Mangino, 1996, Structure of the crust and upper mantle in the south Caspian basin and surrounding region: 18th Annual Seismic Research Symposium on Monitoring a Comprehensive Test Ban Treaty, Phillips laboratory, p. 400-409.

Research, Group for Lithospheric Structure in Tunesia, 1992, The EGT'85 seismic experiment in Tunisia: a reconnaissance of the deep structures: Tectonophysics, v. 207, p. 245-267.

Rhim, R., J. Makris, and L. Moller, 1991, Seismic survey in the northern Red Sea: asymmetric crustal structure: Tectonophysics, v. 198, p. 279-295.

Rodgers, A. J., W. R. Walter, Y. S. Zhang, R. J. Mellors, and A. M. S. Al-Amri, 1998, Lithospheric structure of the Arabian shield and platform from complete regional waveform modeling and surface wave group velocities, submitted to Geophysical Journal International, UCRL-JC-1320908, Lawrence Livermore National Laboratory.

Rodgers, A. J., J. F. Ni, and T. M. Hearn, 1997, Propagation Characteristics of Short-Period Sn and Lg in the Middle East: Bulletin of the Seismological Society of America, v. 87, 396-413.

Sandvol, E., D. Seber, A. Calvert, M. Barazangi, 1998, Grid search modeling of receiver functions: Implications for crustal structure in the Middle East and North Africa, Journal of Geophysical Research, 103, 26,899-26,918. 
Sandvol, E., D. Seber, M. Barazangi, F. Vernon, R. Mellors, and Abdullah AlAmri, Lithospheric seismic velocity structure beneath the Arabian shield, 1998, Geophysical Research Letters, 25, 2873-2876.

Schultz, C. A., S. C. Myers, J. Hipp and C. J. Young, 1998, Nonstationary Baysian kriging: a predictive technique to generate spatial corrections for seismic detection, location and identification, Bulletin of the Seismological Society of America, 88, 1275-1288.

Schweitzer, J., 1995, Blockage of regional seismic waves by the TeisseyreTornquist zone: Geophysical Journal International, v. 123, p. 260-276.

Seber, D., and B. J. Mitchell, 1992, Attenuation of surface waves across the Arabian peninsula: Tectonophysics, v. 204, p. 137-150.

Snyder, D. B., and M. Barazangi, 1986, Deep crustal structure and flexure of the Arabian plate beneath the Zagros collisional mountain belt as inferred from gravity observations: Tectonics, v. 5, p. 361-373.

Suleiman, A. S., and D. I. Doser, 1995, The seismicity, seismotectonics and earthquake hazards of Libya, with detailed analysis of the 1935 April 19, M = 7.1 earthquake sequence: Geophysical Journal International, v. 120, p. 312-322.

Tsukuda, T., K. Sakai, S. Hashimoto, et al., 1991, Aftershock distribution of the 1990 Rudbar, northwest Iran, earthquake of M7.3 and its tectonic implications: Bulletin of the Earthquake Research Institute, Tokyo University, v. 66, p. 351381.

Yegorova, T. P., V. I. Starostenko, V. G. Kozlenko, and N. I. Pavlenkova, 1997, Three-dimensional gravity modelling of the European Mediterranean lithosphere: Geophysical Journal International, v. 129, p. 355-367. 
Zonenshain, L. P., and X. L. Pichon, 1986, Deep basins of the Black Sea and Caspian Sea as remnants of Mesozoic back-arc basins: Tectonophysics, v. 123, p. 181-211. 


\section{Appendix}

Velocity models for geophysical regions. Depths are in kilometers, velocities are in $\mathrm{km} / \mathrm{s}$. Models are based on the Crust5.1 model of Mooney et al. (1998); mantle Vs values are adjusted to be consistent with a $\mathrm{Vp} / \mathrm{Vs}$ ratio of 1.77 .

Region 1 Model Crust5.1 A0

\begin{tabular}{|c|c|c|c|}
\hline Depth & $\underline{V p}$ & $\underline{\mathrm{Vs}}$ & density \\
\hline 0.00 & 1.50 & 0.00 & 1.02 \\
\hline 5.00 & 1.80 & 0.70 & 1.70 \\
\hline 5.15 & 5.00 & 2.50 & 2.60 \\
\hline 6.85 & 6.60 & 3.65 & 2.90 \\
\hline 9.15 & 7.10 & 3.90 & 3.05 \\
\hline 11.65 & 8.15 & 4.61 & 3.40 \\
\hline
\end{tabular}

Region 2 Model Crust5.1 B4*

\begin{tabular}{|c|c|c|c|}
\hline Depth & $\underline{V p}$ & $\underline{\mathrm{VS}}$ & density \\
\hline 0.00 & 1.50 & 0.00 & 1.02 \\
\hline 5.00 & 2.30 & 1.10 & 2.20 \\
\hline 8.50 & 3.20 & 1.60 & 2.30 \\
\hline 11.20 & 5.00 & 2.50 & 2.60 \\
\hline 14.50 & 6.60 & 3.65 & 2.90 \\
\hline 19.00 & 7.10 & 3.90 & 3.05 \\
\hline 24.00 & 8.00 & 4.52 & 3.35 \\
\hline
\end{tabular}

Region 3 Model Crust5.1 Y2

$\begin{array}{rllll}\frac{\text { Depth }}{0.00} & & \frac{V p}{V s} & \text { density } \\ 1.00 & & 2.20 & 1.10 & 2.20 \\ 8.00 & & 6.00 & 2.00 & 2.40 \\ 13.00 & & 6.60 & 3.40 & 2.70 \\ 19.00 & & 7.20 & 4.00 & 2.90 \\ 26.00 & & 8.00 & 4.52 & 3.35\end{array}$

Region 4 Model Crust5.1 Y1*

\begin{tabular}{|c|c|c|c|}
\hline Depth & $\underline{\mathrm{Vp}}$ & $\underline{\mathrm{Vs}}$ & density \\
\hline 0.00 & 2.50 & 1.10 & 2.10 \\
\hline 2.50 & 6.00 & 3.40 & 2.70 \\
\hline 9.50 & 6.60 & 3.70 & 2.90 \\
\hline 16.50 & 7.20 & 4.00 & 3.05 \\
\hline 23.50 & 7.90 & 4.46 & 3.35 \\
\hline
\end{tabular}


Region 5 Model Crust5.1 I7

\begin{tabular}{|c|c|c|c|}
\hline Depth & $\underline{V p}$ & $\underline{\mathrm{VS}}$ & density \\
\hline 0.00 & 2.50 & 1.10 & 2.10 \\
\hline 0.50 & 4.00 & 2.10 & 2.40 \\
\hline 1.00 & 6.20 & 3.60 & 2.80 \\
\hline 14.00 & 6.60 & 3.70 & 2.90 \\
\hline 28.00 & 7.30 & 4.00 & 3.10 \\
\hline 42.00 & 8.20 & 4.63 & 3.40 \\
\hline
\end{tabular}

Region 6 Model Crust5.1 I2*

\begin{tabular}{|c|c|c|c|}
\hline Depth & $V p$ & $\underline{\mathrm{Vs}}$ & density \\
\hline 0.00 & 2.50 & $\overline{1.10}$ & 2.10 \\
\hline 0.10 & 4.00 & 2.10 & 2.40 \\
\hline 1.00 & 6.20 & 3.60 & 2.80 \\
\hline 14.00 & 6.60 & 3.70 & 2.90 \\
\hline 28.00 & 7.30 & 4.00 & 3.10 \\
\hline 40.00 & 7.90 & 4.46 & 3.35 \\
\hline
\end{tabular}

Region 7 Model Crust5.1 D2*

\begin{tabular}{|c|c|c|c|}
\hline Depth & $V p$ & Vs & density \\
\hline 0.00 & 2.50 & 1.10 & 2.10 \\
\hline 2.00 & 4.50 & 2.40 & 2.50 \\
\hline 11.00 & 6.20 & 3.60 & 2.80 \\
\hline 21.00 & 6.60 & 3.70 & 2.90 \\
\hline 34.00 & 7.30 & 4.00 & 3.10 \\
\hline 42.00 & 8.10 & 4.58 & 3.40 \\
\hline
\end{tabular}

Region 8 Model Crust5.1 T5*

\begin{tabular}{|c|c|c|c|}
\hline Depth & $V p$ & Vs & density \\
\hline 0.00 & 2.50 & 1.10 & 2.10 \\
\hline 1.00 & 4.00 & 2.10 & 2.40 \\
\hline 5.00 & 6.00 & 3.40 & 2.70 \\
\hline 14.00 & 6.60 & 3.70 & 2.90 \\
\hline 24.00 & 7.20 & 4.00 & 3.10 \\
\hline 34.00 & 8.00 & 4.52 & 3.35 \\
\hline
\end{tabular}

Region 9 Model Crust5.1 T6

\begin{tabular}{|c|c|c|c|}
\hline Depth & $\underline{V p}$ & $\underline{\mathrm{Vs}}$ & $\underline{\text { density }}$ \\
\hline 0.00 & 2.50 & 1.10 & 2.10 \\
\hline 0.50 & 4.00 & 2.10 & 2.40 \\
\hline 1.00 & 6.00 & 3.40 & 2.70 \\
\hline 12.00 & 6.60 & 3.70 & 2.90 \\
\hline 24.00 & 7.20 & 4.00 & 3.10 \\
\hline 34.00 & 8.20 & 4.63 & 3.40 \\
\hline
\end{tabular}


Region 10, 13, 14, 15 Model Crust5.1 P1

\begin{tabular}{|c|c|c|c|}
\hline Depth & $V p$ & VS & density \\
\hline 0.00 & 2.50 & 1.10 & 2.10 \\
\hline 1.00 & 4.00 & 2.10 & 2.40 \\
\hline 2.00 & 6.10 & 3.50 & 2.75 \\
\hline 22.00 & 6.30 & 3.60 & 2.80 \\
\hline 42.00 & 7.20 & 4.00 & 3.10 \\
\hline 46.00 & 7.90 & 4.46 & 3.35 \\
\hline
\end{tabular}

Region 11 Model Crust5.1 Q0*

\begin{tabular}{|c|c|c|c|}
\hline Depth & $\underline{V p}$ & V $\underline{s}$ & density \\
\hline 0.00 & 2.50 & 1.10 & 2.10 \\
\hline 1.00 & 5.30 & 3.10 & 2.60 \\
\hline 4.00 & 6.10 & 3.50 & 2.75 \\
\hline 26.00 & 6.60 & 3.80 & 2.90 \\
\hline 42.00 & 7.20 & 4.00 & 3.10 \\
\hline 46.00 & 7.90 & 4.46 & 3.35 \\
\hline
\end{tabular}

Region 12 Model Crust5.1 R0*

\begin{tabular}{|c|c|c|c|}
\hline Depth & $V p$ & $\mathrm{Vs}$ & density \\
\hline 0.00 & 2.50 & 1.10 & 2.10 \\
\hline 1.00 & 4.00 & 2.10 & 2.40 \\
\hline 9.00 & 6.00 & 3.50 & 2.70 \\
\hline 19.00 & 6.40 & 3.70 & 2.85 \\
\hline 39.00 & 7.10 & 3.90 & 3.05 \\
\hline 50.00 & 8.00 & 4.52 & 3.35 \\
\hline
\end{tabular}

Region 13, 14, and 15 (see model for Region 10)

Region 16 Model Crust5.1 L1 $^{*}$
\begin{tabular}{cccl} 
Depth & Vp & Vs & density \\
\hline 0.00 & 2.50 & 1.10 & 2.10 \\
1.00 & 4.00 & 2.10 & 2.40 \\
4.00 & 6.00 & 3.50 & 2.70 \\
12.00 & 6.60 & 3.70 & 2.90 \\
29.00 & 7.20 & 4.00 & 3.10 \\
40.00 & 8.00 & 4.52 & 3.35
\end{tabular}


Region 17 Model Crust5.1 T7*

$\begin{array}{cllll}\frac{\text { Depth }}{0.00} & & \frac{V p}{2.50} & \frac{V s}{1.10} & \frac{\text { density }}{2.10} \\ 1.00 & & 4.00 & 2.10 & 2.40 \\ 3.50 & & 6.00 & 3.40 & 2.70 \\ 13.50 & 6.60 & 3.70 & 2.90 \\ 24.00 & 7.20 & 4.00 & 3.10 \\ 34.00 & 7.90 & 4.46 & 3.35\end{array}$

Region 18 Model Crust5.1 A0*

\begin{tabular}{|c|c|c|c|}
\hline Depth & $\underline{V p}$ & Vs & density \\
\hline 0.00 & 1.80 & 0.70 & 1.70 \\
\hline 0.15 & 5.00 & 2.50 & 2.60 \\
\hline 1.85 & 6.60 & 3.65 & 2.90 \\
\hline 4.15 & 7.10 & 3.90 & 3.05 \\
\hline 6.65 & 7.80 & 4.41 & 3.35 \\
\hline
\end{tabular}

Region 19 Model Crust5.1 I2*

\begin{tabular}{|c|c|c|c|}
\hline Depth & $\underline{V p}$ & $\underline{V S}$ & density \\
\hline 0.00 & 2.50 & 1.10 & 2.10 \\
\hline 0.10 & 4.00 & 2.10 & 2.40 \\
\hline 0.90 & 6.20 & 3.60 & 2.80 \\
\hline 11.00 & 6.60 & 3.70 & 2.90 \\
\hline 21.00 & 7.30 & 4.00 & 3.10 \\
\hline 33.00 & 7.90 & 4.46 & 3.35 \\
\hline
\end{tabular}

Region 20 Model Crust5.1 Y7

$\begin{array}{cllll}\text { Depth } & & \frac{V p}{V s} & & \text { density } \\ 0.00 & & 2.50 & 1.10 & 2.10 \\ 1.00 & & 4.00 & 2.10 & 2.40 \\ 12.00 & & 6.00 & 3.40 & 2.70 \\ 17.00 & & 6.60 & 3.70 & 2.90 \\ 29.00 & 7.10 & 3.90 & 3.05 \\ 41.00 & & 8.15 & 4.60 & 3.40\end{array}$

Region 21, 25 Model Crust5.1 D9

\begin{tabular}{|c|c|c|c|}
\hline Depth & $\underline{V p}$ & $\mathrm{Vs}$ & density \\
\hline 0.00 & 2.50 & 1.10 & 2.10 \\
\hline 0.50 & 4.00 & 2.10 & 2.40 \\
\hline 1.00 & 6.20 & 3.60 & 2.80 \\
\hline 17.00 & 6.60 & 3.70 & 2.90 \\
\hline 32.00 & 7.30 & 4.00 & 3.10 \\
\hline 41.00 & 8.20 & 4.63 & 3.40 \\
\hline
\end{tabular}


Region 22, 23 Model Crust5.1 D6

\begin{tabular}{|c|c|c|c|}
\hline Depth & $\underline{\mathrm{Vp}}$ & $\underline{V S}$ & density \\
\hline 0.00 & 2.50 & 1.10 & 2.10 \\
\hline 0.50 & 4.00 & 2.10 & 2.40 \\
\hline 2.00 & 6.20 & 3.60 & 2.80 \\
\hline 17.00 & 6.60 & 3.70 & 2.90 \\
\hline 32.00 & 7.30 & 4.00 & 3.10 \\
\hline 41.00 & 8.20 & 4.63 & 3.40 \\
\hline
\end{tabular}

Region 24 Model Crust5.1 DB

\begin{tabular}{|c|c|c|c|}
\hline Depth & $V p$ & $\underline{V s}$ & density \\
\hline 0.00 & 2.50 & 1.10 & 2.10 \\
\hline 0.50 & 4.00 & 2.10 & 2.40 \\
\hline 3.00 & 6.20 & 3.60 & 2.80 \\
\hline 18.00 & 6.60 & 3.70 & 2.90 \\
\hline 32.00 & 7.30 & 4.00 & 3.10 \\
\hline 41.00 & 8.20 & 4.63 & 3.40 \\
\hline
\end{tabular}

Region 25 (see model for Region 21)

Region 26 Model Crust5.1 N4*

\begin{tabular}{|c|c|c|c|}
\hline Depth & Vp & $\underline{\mathrm{VS}}$ & density \\
\hline 0.00 & 2.50 & 1.10 & 2.10 \\
\hline 1.00 & 5.00 & 2.90 & 2.50 \\
\hline 2.00 & 6.10 & 3.50 & 2.75 \\
\hline 13.00 & 6.30 & 3.60 & 2.80 \\
\hline 24.00 & 6.60 & 3.60 & 2.90 \\
\hline 35.00 & 8.00 & 4.52 & 3.35 \\
\hline
\end{tabular}

Region 27_Model Crust5.1 P2

\begin{tabular}{|c|c|c|c|}
\hline Depth & Vp & $\underline{\mathrm{VS}}$ & density \\
\hline 0.00 & 2.50 & $\overline{1.10}$ & 2.10 \\
\hline 1.00 & 4.00 & 2.10 & 2.40 \\
\hline 2.00 & 6.10 & 3.50 & 2.75 \\
\hline 16.00 & 6.30 & 3.60 & 2.80 \\
\hline 31.00 & 7.20 & 4.00 & 3.10 \\
\hline 38.00 & 8.00 & 4.52 & 3.35 \\
\hline
\end{tabular}

Region 28 Model Crust5.1 N3

\begin{tabular}{|c|c|c|c|}
\hline Depth & $\mathrm{Vp}$ & Vs & density \\
\hline 0.00 & 2.50 & 1.10 & 2.10 \\
\hline 0.50 & 5.00 & 2.90 & 2.50 \\
\hline 1.50 & 6.10 & 3.50 & 2.75 \\
\hline 11.00 & 6.30 & 3.60 & 2.80 \\
\hline 21.00 & 6.60 & 3.60 & 2.90 \\
\hline 31.00 & 8.00 & 4.52 & 3.35 \\
\hline
\end{tabular}




\section{Figure Captions}

Figure 1. Map of the region studied in this report showing color shaded topography and bathemetry, earthquakes from the NEIC bulletin (yellow circles are depth less than $50 \mathrm{~km}$, orange circles are depth $50-200 \mathrm{~km}$, red circles are depths $>200 \mathrm{~km}$, and blue are unknown depth designated $33 \mathrm{~km}$ by NEIC), primary and secondary IMS seismic stations (stars and diamonds), and geophysical regions defined in this study (various color outlines with number designations). A one degree grid is superimposed indicating the resolution of the computer reference models. 
Table 1. Properties of geophysical regions. Asterisk next to velocity model designation indicates a modification from the Cust5.1 model of Mooney et al. (1998). See Appendix for a listing of the velocity models.

\begin{tabular}{|c|c|c|c|c|c|c|c|}
\hline & Crust type and setting & Thickness & Sediments & Regional phases & Seismicity & Velocity & Comments \\
\hline 1 & Oceanic, Atlantic, Indian & $6-11 \mathrm{~km}$ & $0-5 \mathrm{~km}$ & $\mathrm{Pn}, \mathrm{Sn}$ & Mixed & $\mathrm{AO}$ & \\
\hline 2 & Oceanic, deep Med & $14-19 \mathrm{~km}$ & $2-10 \mathrm{~km}$ & $\mathrm{Pn}, \mathrm{Sn}$ & Mixed & $\mathrm{B} 4 *$ & \\
\hline 3 & Black Sea, S. Caspian & $20-21 \mathrm{~km}$ & $8-20 \mathrm{~km}$ & $\mathrm{Pn}, \mathrm{Sn}$ & Low & $Y 2$ & \\
\hline 4 & Red Sea rift & $21-23 \mathrm{~km}$ & $0-5 \mathrm{~km}$ & $\mathrm{Pn}, \mathrm{Sn}$ & Moderate & $Y 1^{*}$ & \\
\hline 5 & African platform & $42 \mathrm{~km}$ & $0-10 \mathrm{~km}$ & $\mathrm{Pn}, \mathrm{Pg}, \mathrm{Lg}$ & Low & 17 & \\
\hline 6 & W. Arabian platform & $38 \mathrm{~km}$ & $0-2 \mathrm{~km}$ & $\mathrm{Pn}, \mathrm{Pg}, \mathrm{Lg}$ & Low & $\mathrm{I} 2 *$ & Low Pn velocity \\
\hline 7 & E. Arabian platform & $46 \mathrm{~km}$ & $2-10 \mathrm{~km}$ & $\mathrm{Pn}, \mathrm{Pg}, \mathrm{Lg}$ & Moderate & $\mathrm{D} 2 *$ & \\
\hline 8 & N. Africa marginal basins & $35 \mathrm{~km}$ & $2-10 \mathrm{~km}$ & $\mathrm{Pn}, \mathrm{Pg}, \mathrm{Lg}$ & Moderate & $T 5^{*}$ & \\
\hline 9 & Atlas-Betic orogen & $35 \mathrm{~km}$ & $0-2 \mathrm{~km}$ & $\mathrm{Pn}, \mathrm{Pg}, \mathrm{Lg}$ & High & T6 & \\
\hline 10 & Kopet Dagh-Alboran & $46 \mathrm{~km}$ & $0-2 \mathrm{~km}$ & $\mathrm{Pn}, \mathrm{Pg}, \mathrm{Lg}$ & High & $\mathrm{P} 1$ & active volcanics \\
\hline 11 & Caucasus orogen & $45 \mathrm{~km}$ & $0-10 \mathrm{~km}$ & $\mathrm{Pn}$ & High & Q0 & \\
\hline 12 & Zagros orogen & $50-60 \mathrm{~km}$ & $0-5 \mathrm{~km}$ & $\mathrm{Pn}, \mathrm{Pg}, \mathrm{Lg}$ & High (deep?) & RO** & salt domes \\
\hline 13 & E. Anatolian, S. Caucasus & $40-45 \mathrm{~km}$ & $0-4 \mathrm{~km}$ & $\mathrm{Pn}$ & $\mathrm{High}$ & $\mathrm{P} 1$ & active volcanics \\
\hline 14 & Turkish plateau & $40-45 \mathrm{~km}$ & $0-5 \mathrm{~km}$ & $\mathrm{Pn}, \mathrm{Pg}, \mathrm{Lg}$ & Moderate & $\mathrm{P} 1$ & \\
\hline 15 & Iranian plateau & $40-50 \mathrm{~km}$ & $0-6 \mathrm{~km}$ & $\mathrm{Pn}, \mathrm{Pg}, \mathrm{Lg}$ & Moderate & $\mathrm{P1}$ & \\
\hline 16 & Makran margin & $35 \mathrm{~km}$ & $0-2 \mathrm{~km}$ & $\mathrm{Pn}, \mathrm{Pg}, \mathrm{Lg}$ & High (deep) & L1* & active volcanics \\
\hline 17 & Aegean-W. Anatolia & $20-30 \mathrm{~km}$ & $0-10 \mathrm{~km}$ & Mixed & $\mathrm{High}$ (deep) & $T 7^{*}$ & \\
\hline 18 & Afar & $8 \mathrm{~km}$ & $0-2 \mathrm{~km}$ & $\mathrm{Pn}, \mathrm{Sn}$ & $\mathrm{High}$ & $\mathrm{AO}^{*}$ & \\
\hline 19 & E. African rift & $30-40 \mathrm{~km}$ & $0 \mathrm{~km}$ & $\mathrm{Pn}, \mathrm{Pg}, \mathrm{Lg}$ ? & Moderate & $12 *$ & volcanic flows \\
\hline 20 & Caspian depression & $40 \mathrm{~km}$ ? & $10-20 \mathrm{~km}$ & $\mathrm{Pn}, \mathrm{Pg}, \mathrm{Lg}$ & Low & $Y 7^{*}$ & salt domes \\
\hline 21 & Kazakh-Russian platform & $45 \mathrm{~km}$ & $0-7 \mathrm{~km}$ & $\mathrm{Pn}, \mathrm{Pg}, \mathrm{Lg}$ & $\mathrm{LoW}$ & D9 & \\
\hline 22 & Caucasus foreland & $40 \mathrm{~km}$ & $2.10 \mathrm{~km}$ & $\mathrm{Pn}, \mathrm{Pg}, \mathrm{Lg}$ & Mod. (deep) & D6 & \\
\hline 23 & Russian platform & $45 \mathrm{~km}$ & $0-? \mathrm{~km}$ & $\mathrm{Pn}, \mathrm{Pg}, \mathrm{Lg}$ & Low & D6 & \\
\hline 24 & Indus basin & $35 \mathrm{~km}$ & $2-6 \mathrm{~km}$ & $? ?$ & Moderate & DB & \\
\hline 25 & Afghan-Hindu Kush & $>45 \mathrm{~km}$ & $0 \mathrm{~km}$ & $\mathrm{Pn}, \mathrm{Pg}, \mathrm{Lg}$ & High (deep) & D9 & \\
\hline 26 & Pannonian Basin & $32 \mathrm{~km}$ & $1-3 \mathrm{~km}$ & $\mathrm{Pn}, \mathrm{Pg}, \mathrm{Lg}$ & Moderate & N4 & \\
\hline 27 & Alps-Appenines-Dinarides & $40-45 \mathrm{~km}$ & $0 \mathrm{~km}$ & $\mathrm{Pn}, \mathrm{Pg}, \mathrm{Lg}$ & $\mathrm{High}$ & $\mathrm{P} 2$ & \\
\hline 28 & Paris Basin-Massif Central & $28-32 \mathrm{~km}$ & $2-3 \mathrm{~km}$ & $\mathrm{Pn}, \mathrm{Pg}, \mathrm{Lg}$ & Low & N33 & \\
\hline
\end{tabular}


$20^{\circ} \mathrm{W} 15^{\circ} \mathrm{W} 10^{\circ} \mathrm{W} 5^{\circ} \mathrm{W} \quad 0^{\circ} \quad 5^{\circ} \mathrm{E} \quad 10^{\circ} \mathrm{E} 15^{\circ} \mathrm{E} 20^{\circ} \mathrm{E} 25^{\circ} \mathrm{E} 30^{\circ} \mathrm{E} 35^{\circ} \mathrm{E} 40^{\circ} \mathrm{E} 45^{\circ} \mathrm{E} 50^{\circ} \mathrm{E} 55^{\circ} \mathrm{E} 60^{\circ} \mathrm{E} 65^{\circ} \mathrm{E} 70^{\circ} \mathrm{E} 75^{\circ} \mathrm{E}$

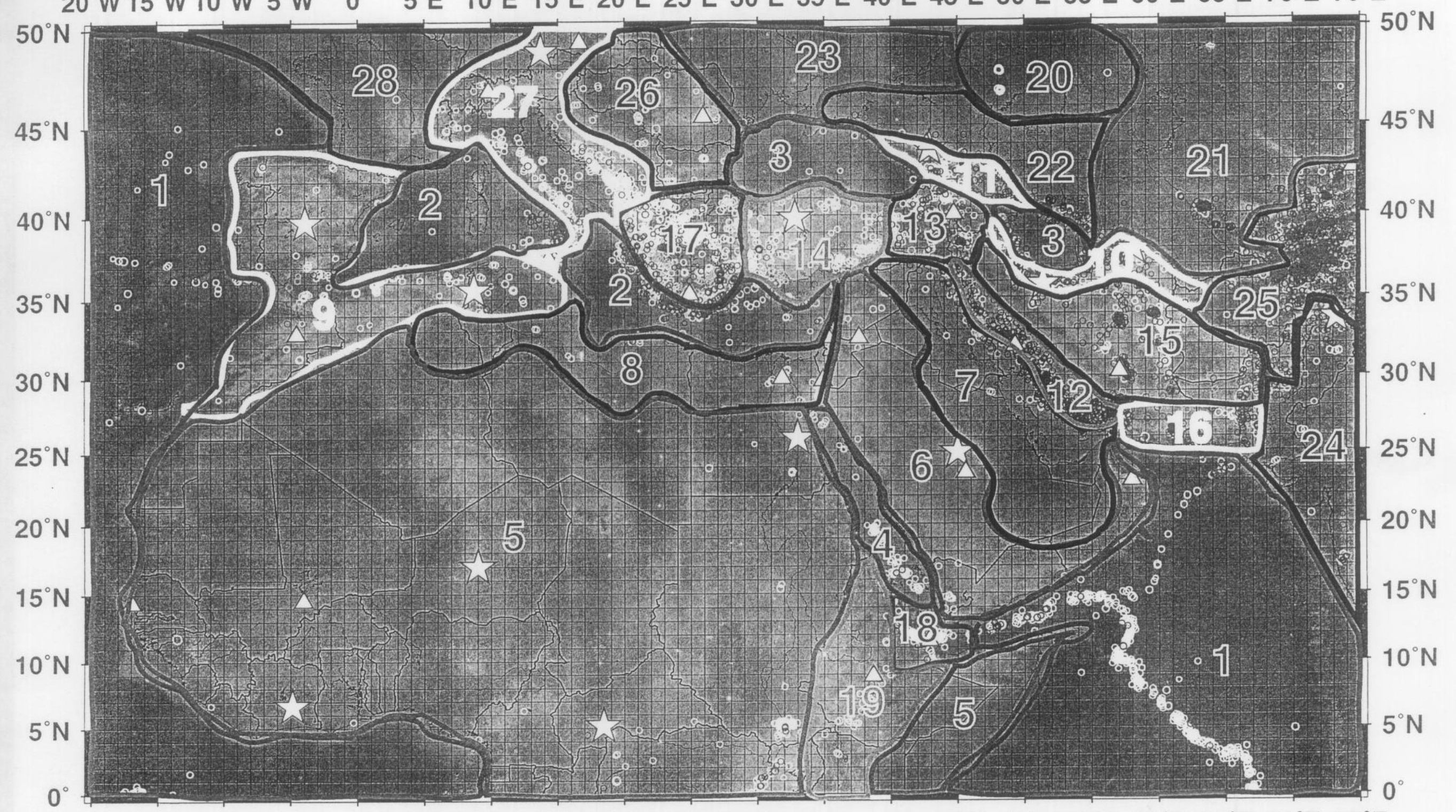
$20^{\circ} \mathrm{W} 15^{\circ} \mathrm{W} 10^{\circ} \mathrm{W} 5^{\circ} \mathrm{W} \quad 0^{\circ} \quad 5^{\circ} \mathrm{E} \quad 10^{\circ} \mathrm{E} 15^{\circ} \mathrm{E} 20^{\circ} \mathrm{E} 25^{\circ} \mathrm{E} 30^{\circ} \mathrm{E} 35^{\circ} \mathrm{E} 40^{\circ} \mathrm{E} 45^{\circ} \mathrm{E} 50^{\circ} \mathrm{E} 55^{\circ} \mathrm{E} 60^{\circ} \mathrm{E} 65^{\circ} \mathrm{E} 70^{\circ} \mathrm{E} 75^{\circ} \mathrm{E}$ 